\title{
Psychological Status of Adolescents with Respiratory Allergic Diseases and Their Caregivers
}

\author{
Solunum Yolu Allerjik Hastalığı Olan Ergenlerin ve Ailelerinin \\ Psikolojik Durumları
}

Duygu Erge1, Pınar Uysal1, Hatice Aksu², Sibelnur Avcil2, Börte Gürbüz Özgür², Faruk Demir², Imran Kurt Ömürlü3, Şahap Dede ${ }^{4}$

1Adnan Menderes University Faculty of Medicine, Children's Health and Diseases Department of Pediatric Allergy and Clinical Immunology, Aydın, Turkey

2Adnan Menderes University Faculty of Medicine, Department of Child and Adolescent Psychiatry, Aydın, Turkey

3Adnan Menderes University Faculty of Medicine, Department of Biostatistics, Aydın, Turkey

${ }^{4}$ Mustafa Kemal University Faculty of Medicine, Department of Psychiatry, Hatay, Turkey

Keywords

Adolescent, allergic rhinitis, anxiety, asthma, depression

\section{Anahtar Kelimeler \\ Adolesan, allerjik rinit, anksiyete, astım, depresyon}

Received/Geliş Tarihi : 08.01.2016

Accepted/Kabul Tarihi : 29.03.2016

doi:10.4274/meandros.2630

Address for Correspondence/Yazışma Adresi: Duygu Erge MD,

Adnan Menderes University Faculty of Medicine, Children's Health and Diseases Department of Pediatric Allergy and Clinical Immunology, Aydın, Turkey

E-mail :duyguolmez@hotmail.com

CCMeandros Medical and Dental Journal, Published by Galenos Publishing.

\begin{abstract}
Objective: The aim of the study was to evaluate the psychological status of adolescents with respiratory allergies and their caregivers.

Materials and Methods: Child and adolescent psychiatrists evaluated the adolescents' psychological status using the Children's Depression Inventory (CDI) and Screen for Child Anxiety-Related Emotional Disorders (SCARED). Psychiatrist evaluated the psychological status of their caregivers using the Hamilton Depression Scale (HAM-D) and the Hamilton Anxiety Scale (HAM-A).

Results: Anxiety symptoms were found in 21 of 63 patients. CDI scores were higher in controls than in patients $(p=0.03)$. HAM-D scores were higher in the caregivers of adolescents with allergic rhinitis and comorbid asthma than in those of controls $(p=0.025)$. None of the scores were affected by the severity of asthma and allergic rhinitis, asthma control levels, presence of an asthma attack in the preceding year as well as by pulmonary function tests ( $p>0.05)$. Moderate and strong positive correlations were found between SCARED and CDI ( $r=0.644$, $p<0.001)$ and HAM-A and HAM-D scores $(r=0.860, p<0.001)$.

Conclusion: Anxiety symptoms were found in one-third of the patients. HAM-D scores were higher in the caregivers of adolescents with allergic rhinitis and comorbid asthma than in those of controls.

Öz

Amaç: Çalışmanın amacı solunum yolu allerjileri olan adölesanların ve ailelerinin psikolojik durumlarının değerlendirilmesidir.

Gereç ve Yöntemler: Çocuk ve adölesan psikiyatristleri adölesanların psikiyatrik durumlarını Çocuklar için Depresyon Ölçeği (CDI) ve Çocuk ve Ergenlerde Anksiyete ve İlgili Bozukluklar için Tarama ve Değerlendirme Ölçeği (SCARED) ile değerlendirdi. Psikiyatristler ailelerin psikolojik durumlarını Hamilton Depresyon Değerlendirme Ölçeği (HAM-D) ve Hamilton Aksiyete Değerlendirme Ölçeği (HAM-A) ile değerlendirdi.

Bulgular: Anksiyete semptomları hastaların 63'ünden 21'inde saptandı. CDI skorları kontrollerde hastalara göre yüksekti $(p=0,03)$. HAM-D skorları allerjik rinit ve eşlik eden astımı olan adölesanların ailelerinde kontrollere göre yüksekti $(p=0,025)$. Hiçbir skor astım ve allerjik rinitin ağırlığından, astım kontrol düzeyinden, son bir yıl içindeki astım atak varlığından ve akciğer fonksiyon testlerinden etkilenmedi $(p>0,05)$. SCARED ve CDI arasında orta düzeyde $(r=0,644$, $p<0,001), H A M-A$ ve HAM-D skorları arasında yüksek düzeyde pozitif korelasyon saptandı $(r=0,860, p<0,001)$.

Sonuç: Aksiyete semptomların hastaların üçte birinde görüldü. HAM-D skorları allerjik rinit ve eşlik eden astımı olan adölesanların ailelerinde kontrollere göre yüksekti.
\end{abstract}




\section{Introduction}

Asthma is the most prevalent chronic disease in childhood (1). Most patients with asthma have concurrent rhinitis, whereas $10 \%-40 \%$ of patients with allergic rhinitis have asthma (2). Studies have shown that the prevalence of rhinitis and asthma are increasing in childhood (3).

Recent publications have shown a relationship between psychological factors and respiratory allergic diseases in children (4). Patients with allergic rhinitis have higher rates of depression, anxiety and psychosocial problems than healthy individuals (5-7). Adolescents with asthma are at an increased risk of comorbid anxiety and depressive disorders compared to healthy adolescents (8). Furthermore, asthma with comorbid allergic rhinitis has a greater negative impact on the psychological status of the patients (9).

A few studies have investigated the impact of mental health problems in caregivers on the outcomes of children with asthma (10-13). Previous studies have reported that caregivers of children with asthma are at an increased risk of symptoms of anxiety and depression $(10,11)$. Brown et al. (12) showed that depressive symptoms in caregivers were associated with higher morbidity in children with asthma. Bitsko et al. (13) suggested that symptoms of depression and anxiety in adolescents with asthma and their caregivers could lead to non-adherence to medications and poor symptom control. Seasondependent increase in suicides was reported in atopic people (14). In a study by Marshall et al., (15) patients with allergic rhinitis sensitized to ragweed pollen had lower positive-affect scores during the ragweed season.

Although there are some data about the psychological or behavioral problems seen in patients with respiratory allergic diseases $(14,15)$, however, there is no evidence in the literature showing the effect of psychological distress on disease control in adolescents at the pollen season. To the best of our knowledge, no study has investigated the psychological status of children and adolescents with asthma and/or allergic rhinitis sensitized to pollen and their caregivers to determine its impact on the outcomes of their respiratory allergies during the pollen season. In this study, we investigated the depression and anxiety status of adolescents with asthma and/or allergic rhinitis sensitized to pollen and their caregivers to determine the impact on their conditions during the pollen season.

\section{Materials and Methods}

This study was conducted at the Department of Pediatric Allergy and Immunology between March and June 2014. Adolescents aged between 120 and 216 months with a diagnosis of asthma and/or allergic rhinitis, sensitized to pollen were invited to participate in this study.

We recorded information including age, gender, medical history, atopic sensitization, severity of asthma and allergic rhinitis, degree of asthma control, pulmonary functions, frequency of asthma attacks, number of admissions to emergency departments due to asthma in the preceding year, number of siblings, caregivers' education, and monthly income.

Skin-prick tests with common aeroallergens were performed according to the European Academy of Allergy and Clinical Immunology recommendations (16). Allergic sensitization to pollens was defined as a positive skin-prick test result to at least one pollen allergen responsible for the respiratory symptoms in spring. In the Aegean region, pollen from grasses, cereals and Olea europaea are the most frequently detected production of which peaks in spring (17).

Asthma was diagnosed according to the Global Initiative for Asthma (GINA) recommendations and based on clinical asthma symptoms and lung function tests. Asthma severity and control was determined according to the GINA guidelines (18). We also used the Asthma Control Test (ACT) to assess the degree of asthma control. It is a validated self-administered questionnaire comprising five questions related to the preceding 4 weeks. Each question includes five response modalities with a score ranging from 1 to 5 , yielding a global arithmetic score ranging from 5 to 25 . A cut-off score of $\leq 19$ identified patients with poorly controlled asthma (19). Pulmonary function tests were performed using a spirometer (MasterScreen ${ }^{\mathrm{TM}}$ Pneumo; Jaeger, North Rhine, Westphalia, Germany). Forced expiratory volume in $1 \mathrm{~s}$, forced vital capacity and maximum mid-expiratory flow (MMEF25-75\%) were measured according to the American Thoracic Society/the European Respiratory Society guidelines (20). The patients performed three consecutive maneuvers and the best result was retained. 
The diagnosis of allergic rhinitis and assessment of its severity were done according to the Allergic Rhinitis and its Impact on Asthma (ARIA) guidelines (21). The severity of allergic rhinitis was also determined using the Visual Analogue Scale (VAS) proposed by the Joint Task Force on Practice Parameters (22). It was found to correlate well with the ARIA guidelines. A VAS score ranging from 0 (nasal symptoms, not at all bothersome) to $10 \mathrm{~cm}$ (nasal symptoms, extremely bothersome) was used to assess the severity of the combined nasal symptoms (23). We also used a VAS for the individual symptoms, such as nasal obstruction, rhinorrhea, sneezing and nasal pruritus.

The Children's Depression Inventory (CDI) and Screen for Child Anxiety-Related Emotional Disorders (SCARED) were used by child and adolescent psychiatrists to determine the psychological status of the children and adolescents. The Hamilton Depression Scale (HAM-D) and the Hamilton Anxiety Scale (HAM-A) were used by psychiatrists to determine the psychological status of their caregivers.

The CDI is a 27-item self-report assessment that evaluates the cognitive, affective and behavioral symptoms of depression during the preceding 2 weeks in children and adolescents aged 8-17 years. Each item is scored as absence ( 0 points), mild presence (1 point) or clear presence ( 2 points), leading to a total score ranging from 0 to 54 . CDI scores of $\geq 19$ are considered clinically indicative of the significant depressive symptomatology (24). The validity and the reliability of the Turkish version were assessed in Turkish children by Öy (25).

The SCARED is a 41-item child/parent reporting instrument used to identify children with anxiety disorders. It examines five factors: somatic symptoms/ panic, generalized anxiety, separation anxiety, social phobia and school phobia. The items in the SCARED are rated on a three-point scale ranging from 0 (not true or hardly ever true) to 2 (true or often true). The total score ranges from 0 to 82. Patients who score $\geq 25$ can be diagnosed with anxiety disorder (26). The validity and the reliability of the Turkish version were tested in Turkish children by Karaceylan (27).

The HAM-A was designed by Hamilton to determine the level of anxiety and distribution of symptoms in individuals. The HAM-A consists of 14 questions that investigate physical and mental symptoms. The score ranges from 0 to 56 . Scores $\geq 14$ are clinically indicative of significant anxiety (28). The reliability and the validity of the Turkish version were analyzed by Yazıcı et al. (29). The HAM-D is a form developed by Hamilton, consisting of 17 questions. A score of $\geq 14$ indicates depression. The reliability and the validity of the Turkish version were confirmed by Akdemir et al. (30).

In this study, healthy controls age- and sex-matched to the patients were enrolled. Their caregivers were also recruited. Demographic data, the SCARED and $C D I$ scores of the healthy adolescents and the HAM-A and HAM-D scores of their caregivers were determined. The depression and the anxiety scores of the patients and their caregivers were compared with those of the healthy controls and their caregivers. The relationships between CDI and SCARED and HAM-A and HAM-D scores and the outcomes of the allergic diseases were evaluated.

The study protocol was approved by the ethics committee of the Adnan Menderes University Faculty of Medicine (Reference number: 2014/351). Written informed consent was obtained from all the adolescents and their caregivers.

\section{Statistical Analysis}

The statistical software package SPSS Statistics for Windows Version 17 (SPSS Inc., Chicago, IL, USA) was used for all the statistical analyses. The KolmogorovSmirnov test was used to evaluate whether the distribution of continuous variables were normal. Comparisons between the groups of normally distributed independent variables, depending on the number of groups, were performed using the independent t-test or one-way analysis of variance (ANOVA) and descriptive statistics were presented as means \pm standard deviation (minimum-maximum). Comparisons between the two groups of non-normally distributed independent variables, depending on the number of groups, were performed using the Mannwhitney $u$ test or Kruskal-Wallis test and descriptive statistics were shown as median (25-75 percentiles). Spearman's rank correlation coefficient was used to assess the correlation between non-normally distributed independent variables. Chi-square test was used to analyze the categorical variables and descriptive statistics were presented as frequencies (\%) for the categorical variables. A p value of less than 0.05 was considered statistically significant. 


\section{Results}

The study group consisted of 63 children with allergic rhinitis and asthma sensitized to pollen. Of those, 16 had allergic rhinitis, 2 had asthma and 45 had asthma and allergic rhinitis. The control group consisted of 43 healthy children. Demographical data together with SCARED, CDI, HAM-A and HAM-D scores in the patients and the healthy controls are shown in Table 1.

A significant moderate positive correlation was determined between SCARED and CDI scores ( $r=0.644$, $p<0.001)$ and a strong positive correlation was found between HAM-A and HAM-D scores $(r=0.86, p<0.001)$. However, a significant weak positive correlation was found between CDI and HAM-A scores $(r=0.217$, $\mathrm{p}=0.031$ ).

The patients and the healthy controls did not differ in age or gender ( $p>0.05$ for each of the parameters). $\mathrm{CDI}$ scores were lower in the patients than in controls $(p=0.03)$. HAM-D scores were higher in the caregivers of patients than in those of controls $(p=0.049)$.
The median SCARED, CDI, HAM-A and HAM-D scores in female patients were 24 (19-38), 9 (4-16), $1.5(0-4)$ and $0.5(0-3)$, respectively. The median SCARED, CDI, HAM-A and HAM-D scores in male patients were 22 (13.75-28.25), 7 (4-13), 3.5 (0-8) and $2(0-6)$, respectively. The SCARED scores were higher in female patients than in male patients $(p=0.021)$.

Monthly family incomes were $<1000$ Turkish Liras (TL) in five, 1000-4000 TL in 49, and $>4000 \mathrm{TL}$ in nine of the patients. They were $<1000 \mathrm{TL}$ in $16,1000-4000$ $\mathrm{TL}$ in 24 , and $>4000 \mathrm{TL}$ in 3 controls. Monthly family incomes were significantly higher in the patient group than that in the control group ( $p=0.001)$. SCARED, CDI, HAM-A and HAM-D scores did not differ according to the monthly family income $(p>0.05$ for each of the parameters).

The number of siblings was significantly higher in the control group $(p=0.002)$. SCARED scores were positively and weakly correlated with the number of siblings ( $r=0.23, p=0.022$ ). In addition, a significant difference was found between the patient and the control groups in terms of graduation from university

Table 1. Comparison of demographic data and parameters between patients and controls

\begin{tabular}{|c|c|c|c|}
\hline & Patients ( $n=63$ ) & Controls ( $n=43$ ) & $p$ value \\
\hline Age (months; mean $\pm S D$ ) (minimum-maximum) & $\begin{array}{l}150.29 \pm 25.45 \\
(120-200)\end{array}$ & $\begin{array}{l}159.56 \pm 22 \\
(120-203)\end{array}$ & NS \\
\hline $\begin{array}{l}\text { Sex (n; Male/female) } \\
\text { Depression [n (\%)] }\end{array}$ & $\begin{array}{l}46 / 17 \\
3(5.1 \%) \\
\end{array}$ & $\begin{array}{l}28 / 15 \\
5\end{array}$ & $\begin{array}{l}\text { NS } \\
\text { NS }\end{array}$ \\
\hline Anxiety [n (\%)] & $21(35.6 \%)$ & 18 & NS \\
\hline Caregivers' depression [n (\%)] & $5(7.9 \%)$ & 2 & NS \\
\hline Caregivers' anxiety [n (\%)] & $7(11.1 \%)$ & 2 & NS \\
\hline SCARED [median (25-75 percentiles)] & $21(14-30)$ & $24(17-32.25)$ & NS \\
\hline CDI [median (25-75 percentiles)] & $6(3-13)$ & $10(5.75-15.25)$ & 0.03 \\
\hline HAM-A [median (25-75 percentiles)] & $3(0-9)$ & $2(0-5)$ & NS \\
\hline HAM-D [median (25-75 percentiles)] & $2(0-6)$ & $0(0-3.5)$ & 0.049 \\
\hline Paternal age (mean $\pm \mathrm{SD}$, minimum-maximum) & $43.48 \pm 6.30(33-65)$ & $43.14 \pm 5.94(32-59)$ & NS \\
\hline Maternal age [median (25-75 percentiles)] & $38(35-42)$ & $39(36-41)$ & NS \\
\hline Paternal atopy $(n)$ & 19 & 5 & 0.045 \\
\hline Maternal atopy $(n)$ & 21 & 5 & 0.02 \\
\hline Fathers graduated from university $(n)$ & 25 & 8 & 0.014 \\
\hline Mothers graduated from university $(n)$ & 17 & 6 & NS \\
\hline Mothers smoking cigarette (n) & 14 & 9 & NS \\
\hline Fathers smoking cigarette $(n)$ & 25 & 20 & NS \\
\hline
\end{tabular}


by fathers but not by mothers $(p=0.014, p>0.05$, respectively).

Allergic rhinitis was mild intermittent in 5, moderate-severe intermittent in 5 , mild persistent in 10 , and moderate-severe persistent in 41 patients. Asthma was intermittent in 1 , mild persistent in 30 , and moderately persistent in 16 patients. Asthma was well controlled in 23, partially controlled in 10 and uncontrolled in 14 patients. The mean ACT score in patients with asthma was $21.63 \pm 4.79$ (8-25). In the preceding year, 21 patients with asthma experienced no asthma attack, 12 experienced one, 5 experienced two, 4 experienced three and five patients experienced more than 3 attacks. Thirteen were admitted to the emergency department once in the preceding year, 2 of them twice, 2 of them 3 times and 3 of them more than 3 times.

No difference was observed between SCARED CDI, HAM-A and HAM-D scores in terms of having mild or moderate-severe allergic rhinitis, having mild or moderate persistent asthma, atopic sensitization, degree of asthma control, occurrence of asthma attacks and emergency department admission related to asthma in the preceding year $(p>0.05$ for each of the parameters).

CDI scores were significantly higher in controls than in patients with allergic rhinitis and asthma $(p=0.015)$. HAM-D scores were significantly higher in the caregivers of patients with asthma and allergic rhinitis than in caregivers of controls $(p=0.025)$.

The median total VAS, nasal obstruction, rhinorrhea, sneezing and pruritis scores in patients with allergic rhinitis were 20 (15.5-27), 5 (4-8), 5 (3-7.5), 6 (3-9) and 5 (1.5-7.5), respectively. A weak positive significant correlation was found between the total VAS and HAM-A scores $(r=0.264, p=0.04)$, pruritus and SCARED scores $(r=0.262, p=0.049)$ and sneezing and HAM-A scores $(r=0.313, p=0.014)$. However, a negative weak correlation was found between rhinorrhea and SCARED scores $(r=-0.265$, $p=0.046$ ).

There were significant differences in ages and ages at diagnosis between adolescents with allergic rhinitis and those with allergic rhinitis and comorbid asthma $(p=0.01$ versus $p=0.002$ ). No difference was observed between these two groups in terms of gender, atopic sensitization and SCARED, CDI, HAM-A and HAM-D scores ( $p>0.05$ for each of the parameters) (Table 2).

Table 2. Comparison of demographic data and parameters between patients with allergic rhinitis and patients with allergic rhinitis and comorbid asthma

\begin{tabular}{|c|c|c|c|}
\hline & Allergic rhinitis ( $n=16)$ & Asthma and allergic rhinitis ( $n=45)$ & p value \\
\hline Age (months; median) (25-75 percentiles) & $172(140.75-185.25)$ & $142(125.5-159.5)$ & 0.01 \\
\hline Gender (Male/female; $n$ ) & $10 / 6$ & $35 / 10$ & NS \\
\hline Diagnosis age [months; median (25-75 percentiles)] & $150(120-168)$ & $120(84-144)$ & 0.002 \\
\hline SCARED [median (25-75 percentiles)] & $22.5(16-25.5)$ & $21(13-34)$ & NS \\
\hline CDI [median (25-75 percentiles)] & $6.5(5.75-14.25)$ & $6(3-13)$ & NS \\
\hline HAM-A [median (25-75 percentiles)] & $1.5(0-4)$ & $4(0-9)$ & NS \\
\hline HAM-D [median (25-75 percentiles)] & $2(0-4)$ & $3(0-8)$ & NS \\
\hline Depression (n) & 1 & 2 & NS \\
\hline Anxiety (n) & 4 & 17 & NS \\
\hline Caregivers' depression (n) & 0 & 4 & NS \\
\hline Caregivers' anxiety (n) & 1 & 6 & NS \\
\hline Maternal atopy (n) & 4 & 16 & NS \\
\hline Paternal atopy $(n)$ & 5 & 12 & NS \\
\hline Grass allergy $(n)$ & 15 & 40 & NS \\
\hline Cereal allergy (n) & 15 & 32 & NS \\
\hline Olea europeae allergy $(n)$ & 6 & 19 & NS \\
\hline Tree allergy (n) & 2 & 4 & NS \\
\hline
\end{tabular}

SCARED: Screen for Child Anxiety-Related Emotional Disorders, CDI: The Children's Depression Inventory, HAM-A: Hamilton Anxiety Scale, HAM-D: Hamilton Depression Scale, SD: Standard deviation, NS: Non significant, $p$ values $<0.05$ were considered statistically significant 


\section{Discussion}

The present study investigating the impact of the psychological status of the caregivers and their adolescents with asthma or/and allergic rhinitis sensitized with pollen on outcomes of their diseases during the pollen season is the first study in the literature. Symptoms of anxiety and depression were reported by $35.6 \%$ and $5.1 \%$ of patients and $11.1 \%$ and $7.9 \%$ of caregivers, respectively.

We found lower $\mathrm{CDI}$ scores in patients than in controls. We related this finding with the lower sociocultural level in controls. In our control group, more siblings, lower graduation rates of the fathers, and lower monthly incomes were observed, although only the number of siblings significantly and positively correlated with SCARED scores. We showed higher HAM-D scores in caregivers of patients than in controls.

Studies have revealed that patients with allergic rhinitis are more likely to experience depression, anxiety and psychosocial problems than healthy people. It has been determined that nasal obstruction and itching in patients with allergic rhinitis had a negative impact on their psychological status (5-7). A large epidemiologic study (31) revealed more than twice the number of children with allergic rhinitis aged 5-6 went on to experience a major depressive episode in the subsequent 17 years than did healthy individuals. In our study, depression and anxiety symptoms were found in a very low rate in children with allergic rhinitis. SCARED and CDI scores did not differ between patients with allergic rhinitis and controls.

Asthma is more common among males in early childhood, but after puberty, the incidence decreases in males (32). We enrolled all the voluntary adolescents with asthma and/or allergic rhinitis sensitized to pollen and applied to our outpatient clinic in the pollen season. Although a male predominance was detected in the study groups, no difference was observed between the patient and control groups in terms of gender.

In the literature, psychological complaints in patients with allergic rhinitis may be related to symptom severity (33). In our study, a weak positive correlation was found between nasal pruritus and SCARED scores. A weak negative correlation was found between rhinorrhea and SCARED scores. No difference was observed between mild and moderatesevere allergic rhinitis in terms of SCARED and CDI scores.

It has been suggested that one-third of adolescents with asthma suffer from an anxiety or panic disorder (34). In an international survey, depression and anxiety were found to be associated with asthma in $65 \%$ and $40 \%$ of 54 countries, respectively (35). However, some studies have failed to find an association between depression and asthma $(36,37)$. In our study, the SCARED and $C D I$ scores in children with allergic rhinitis did not differ from those in patients with allergic rhinitis and comorbid asthma. Depression and anxiety symptoms were found in 2 and 17 of 45 patients with allergic rhinitis and comorbid asthma, respectively. Although SCARED scores in adolescents with asthma and allergic rhinitis did not differ from the scores in healthy controls, CDI scores were significantly higher in controls than in patients with asthma and allergic rhinitis.

The relationship between asthma severity and anxiety or depression is still a matter of debate (38-42). In our study, no correlations were evident between ACT and SCARED and CDI scores in patients with asthma. Additionally, no difference was found in SCARED and CDI scores according to the degree of asthma control as classified by the GINA guidelines.

Pietras et al. (43) suggested that mild depressive symptoms are present in $26 \%$ of individuals with mild asthma, whereas moderate depressive symptoms are present in $36 \%$ of patients with moderate asthma. One study showed a significant decrease in pulmonary function tests in patients with depression (44). In our study, SCARED and CDI scores did not differ between patients with mild and moderate persistent asthma. We also identified no relationships between the pulmonary function tests and the SCARED and CDI scores in patients with asthma. Depression and anxiety in patients with asthma may lead to nonadherence to medication, poor asthma outcomes and worse asthma symptoms compared with patients with asthma having no psychological disturbances $(45,46)$. In our study, no differences were shown between the SCARED and CDI scores in patients with asthma in terms of the number of asthma attacks or asthmarelated admissions to the emergency departments in the preceding year. 
To the best of our knowledge, there is no study evaluating the psychological status of the caregivers of children with allergic rhinitis. In our study HAM-A and HAM-D scores did not differ between the caregivers of allergic rhinitis and the caregivers of controls. Weak positive correlations were found between the total VAS and HAM-A scores, and sneezing and HAM-A scores.

Previous studies have suggested that caregivers of patients with asthma were at increased risk of anxiety and depression than those of healthy individuals $(10,11)$. HAM-D scores were significantly higher in the caregivers of patients with asthma and allergic rhinitis than in the caregivers of controls. The asthmatic children of the caregivers with a depression and/or anxiety disorder exhibited reduced pulmonary function compared with those of the healthy caregivers (47). In our study, no correlations were evident between ACT scores and the pulmonary function tests of children with asthma and the HAM-A and HAM-D scores of their caregivers. In addition, no differences were found in the HAM-A and HAM-D scores of the caregivers of patients with asthma, in terms of the level of asthma control, asthma severity, asthma attacks and asthma-related admissions to the emergency services in the preceding year.

\section{Study Limitations}

Although the low number of the subjects in the study groups was the limitation of our study, we assume that assessment of the depressive and anxiety symptoms of the adolescents and their caregivers by the specialist doctors made the study valuable. Larger studies are required to evaluate the increased risk of depression and anxiety in pollen allergic patients and their caregivers in the pollen season.

\section{Ethics}

Ethics Committee Approval: The study protocol was approved by the ethics committee of the Adnan Menderes University Faculty of Medicine (Reference number: 2014/351), Informed Consent: Written informed consent was obtained from all the adolescents and their caregivers.

Peer-review: Externally and internally peerreviewed.

\section{Authorship Contributions}

Concept: Duygu Erge, Pınar Uysal, Hatice Aksu, İmran Kurt Ömürlü, Design: Börte Gürbüz Özgür, Faruk
Demir, Şahap Dede, Data Collection or Processing: Börte Gürbüz Özgür, Faruk Demir, İmran Kurt Ömürlü, Şahap Dede, Analysis or Interpretation: Duygu Erge, Pınar Uysal, Faruk Demir, İmran Kurt Ömürlü, Börte Gürbüz Özgür, Literature Search: Sibelnur Avcil, Writing: Duygu Erge, Pınar Uysal, Hatice Aksu.

Conflict of Interest: No conflict of interest was declared by the authors.

Financial Disclosure: The authors declared that this study received no financial support.

\section{References}

1. Masoli M, Fabian D, Holt S, Beasley R. Global Initiative for Asthma (GINA) Program. The global burden of asthma: executive summary of the GINA Dissemination Committee report. Allergy 2004; 59: 469-78.

2. Cruz AA, Popov T, Pawankar R, Annesi-Maesano I, Fokkens W, Kemp J, et al. ARIA Initiative Scientific Committee. Common characteristics of upper and lower airways in rhinitis and asthma: ARIA update, in collaboration with GA(2)LEN. Allergy 2007; 62: 1-41.

3. Asher MI, Montefort S, Björkstén B, Lai CK, Strachan DP, Weiland SK, et al. ISAAC Phase Three Study Group. Worldwide time trends in the prevalence of symptoms of asthma, allergic rhinoconjunctivitis, and eczema in childhood: ISAAC Phases One and Three repeat multicountry cross-sectional surveys. Lancet 2006; 368: 733-43.

4. Slattery MJ, Essex MJ. Specificity in the association of anxiety, depression, and atopic disorders in a community sample of adolescents. J Psychiatr Res 2011; 45: 788-95.

5. Meltzer EO, Blaiss MS, Derebery MJ, Mahr TA, Gordon BR, Sheth $\mathrm{KK}$, et al. Burden of allergic rhinitis: results from the Pediatric Allergies in America survey. J Allergy Clin Immunol 2009; 124: 43-70.

6. Wu WC, Chang HY, Kuo KN, Chen CY, Tu YC, Yang YH. Psychosocial problems in children with allergic diseases: a population study in Taiwan. Child Care Health Dev. 2011; 37: 662-70.

7. Lv X, Xi L, Han D, Zhang L. Evaluation of the psychological status in seasonal allergic rhinitis patients. ORL J Otorhinolaryngol Relat Spec 2010; 72: 84-90.

8. Katon W, Lozano P, Russo J, McCauley E, Richardson L, Bush. The prevalence of DSM-IV anxiety and depressive disorders in youth with asthma compared with controls. J Adolesc Health 2007; 41: 455-63.

9. Xi L, Zhang $Y$, Han D, Zhang L. Effect of asthma, aeroallergen category, and gender on the psychological status of patients with allergic rhinitis. J Investig Allergol Clin Immunol 2012; 22: 264-9.

10. Szabo A, Mezei G, Kovari E, Cserháti E. Depressive symptoms amongst asthmatic children's caregivers. Pediatr Allergy Immunol 2010; 21: 667-73.

11. Yuksel H, Sogut A, Yilmaz O,Demet M, Ergin D, Kirmaz C. Evaluation of sleep quality and anxiety-depression parameters 
in asthmatic children and their mothers. Respir Med 2007; 101: 2550-4.

12. Brown ES, Gan V, Jeffress J, Mullen-Gingrich K, Khan DA, Wood $\mathrm{BL}$, et al. Psychiatric symptomatology and disorders in caregivers of children with asthma. Pediatrics 2006; 118: 1715-20.

13. Bitsko MJ, Everhart RS, Rubin BK. The adolescent with asthma. Paediatr Respir Rev 2014; 15: 146-53.

14. Timonen M, Viilo K, Hakko H, Särkioja T, Meyer-Rochow VB, Väisänen $E$, et al. Is seasonality of suicides stronger in victims with hospital treated atopic disorders? Psychiatry Res 2004; 126: 167-75.

15. Marshall PS, O'Hara C, Steinberg P. Effects of seasonal allergic rhinitis on fatigue levels. Psychosom Med 2002; 64: 684-91.

16. Dreborg S, Frew A. Allergen standardization and skin tests. EAACl Position paper. Allergy 1993; 48: 49-54.

17. Tezcan D, Uzuner N, Sule Turgut C, Karaman O, Köse S. Retrospective evaluation of epidermal skin prick tests in patients living in Aegean region. Allergol Immunopathol (Madr) 2003; 31: 226-30.

18. Global Initiative for Asthma (GINA): Global Strategy for Asthma Management and Prevention: Revised 2014.

19. Nathan RA, Sorkness CA, Kosinski M, Schatz M, Li JT, Marcus $P$, et al. Development of the asthma control test: a survey for assessing asthma control. J Allergy Clin Immunol 2004; 113: 5965.

20. Miller MR, Hankinson J, Brusasco V, Burgos F, Casaburi R, Coates A, et al. Standardisation of spirometry. Eur Respir J 2005; 26: 319-38.

21. Bousquet J, Khaltaev N, Cruz AA, Denburg J, Fokkens WJ, Togias A, et al. World Health Organization; GA(2)LEN; AllerGen. Allergic Rhinitis and its Impact on Asthma (ARIA) 2008 update (in collaboration with the World Health Organization, GA(2)LEN and AllerGen). Allergy 2008; 63: 8-160.

22. Spector SL, Nicklas RA, Chapman JA, Bernstein IL, Berger WE, Blessing-Moore J, et al. Joint Task Force on Practice Parameters; American Academy of Allergy, Asthma, and Immunology; American College of Allergy, Asthma, and Immunology; Joint Council of Allergy, Asthma, and Immunology. Symptom severity assessment of allergic rhinitis: part 1. Ann Allergy Asthma Immunol 2003; 91: 105-14.

23. Bousquet PJ, Combescure $C$, Neukirch F, Klossek JM, Méchin H, Daures JP, et al. Visual analog scales can assess the severity of rhinitis graded according to ARIA guidelines. Allergy 2007; 62: 367-72.

24. Kovacs M. The Children Depression Inventory (CDI). Psychopharmacol Bull 1985; 21: 995-8.

25. Öy B. Children's Depression Inventory: depression scale for children: study of validity and reliability. Turk Psikiyatri Derg 1991; 2: 132-6.

26. Birmaher B, Brent DA, Chiappetta L, Bridge J, Monga S, Baugher $M$. Psychometric properties of the screen for child anxiety related emotional disorders (SCARED): a replication study. J Am Acad Child Adolesc Psychiatry 1999; 38: 1230-6.
27. Karaceylan CF. The screen for child anxiety related emotional disorders: A study of reliability and validity. Unpublished Master's Thesis, Kocaeli University, Turkey, 2004.

28. Hamilton A. Diagnosis and rating of anxiety. Br J Psychiatry 1969; 3: 76-9.

29. Yazıcı MK, Demir B, Tanrıverdi N. Hamilton Anksiyete Degerlendirme Ölceği; Degerlendiriciler Arası Güvenirlik ve Geçerlik Çalısması. Turk Psikiyatri Derg 1998; 9: 114-7.

30. Akdemir A, Örsel S, Dağ I, Türkçapar H, İşcan N, Özbay $H$. Hamilton depresyon derecelendirme ölçeği (HDDÖ)'nin geçerliği, güvenirliği ve klinikte kullanımı. Psikiyatri Psikoloji Psikofarmakoloji Dergisi 1996; 4: 251-9.

31. Cohen P, Pine D, Must A, Kasen S, Brook J. Prospective associations between somatic illness and mental illness from childhood to adulthood. Am J Epidemiol 1998; 147: 232-9.

32. de Marco R, Locatelli F, Sunyer J, Burney $P$, the European Community Respiratory Health Survey Study Group. Differences in incidence of reported asthma related to age in men and women. Am J Respir Crit Care Med 2000; 162: 68-74.

33. Bavbek $\mathrm{S}$, Kumbasar $\mathrm{H}$, Tuğcu H, Misirligil Z. Psychological status of patients with seasonal and perennial allergic rhinitis. J Investig Allergol Clin Immunol 2002; 12: 204-10.

34. Katon WJ, Richardson L, Lozano P, McCauley E. The relationship of asthma and anxiety disorders. Psychosom Med 2004; 66: 349-55.

35. Wong KO, Hunter Rowe B, Douwes J, Senthilselvan A. Asthma and wheezing are associated with depression and anxiety in adults: an analysis from 54 countries. Pulm Med 2013; 2013: 929028.

36. McQuaid EL, Kopel SJ, Nassau JH. Behavioral adjustment in children with asthma: a meta-analysis. J Dev Behav Pediatr 2001; 22: 430-9.

37. Bender BG, Annett RD, Iklé D, DuHamel TR, Rand C, Strunk RC. Relationship between disease and psychological adaptation in children in the Childhood Asthma Management Program and their families. CAMP Research Group. Arch Pediatr Adolesc Med 2000; 154: 706-13.

38. Letitre SL, de Groot EP, Draaisma E, Brand PL. Anxiety, depression and self-esteem in children with well-controlled asthma: casecontrol study. Arch Dis Child 2014; 99: 744-8.

39. Di Marco F, Verga M, Santus P, Giovannelli F, Busatto P, Neri M, et al. Close correlation between anxiety, depression, and asthma control. Respir Med 2010; 104: 22-8.

40. Liu S, Wu R, Li L, Liu L, Li G, Zhang $X$, et al. The prevalence of anxiety and depression in Chinese asthma patients. PLoS One 2014; 9: 103014.

41. Trzcińska H, Przybylski G, Kozłowski B, Derdowski S. Analysis of the relation between level of asthma control and depression and anxiety. Med Sci Monit 2012; 18: 190-4.

42. Vieira AA, Santoro IL, Dracoulakis S, Caetano LB, Fernandes AL. Anxiety and depression in asthma patients: impact on asthma control. J Bras Pneumol 2011; 37: 13-8.

43. Pietras T, Panek M, Witusik A, Wujcik R, Szemraj J, Górski P, et al. Analysis of the correlation between level of anxiety, intensity of depression and bronchial asthma control. Post Dermatol Alergol 2011; 28: 15-22. 
44. Krommydas GC, Gourgoulianis KI, Angelopoulos NV, Kotrotsiou E, Raftopoulos V, Molyvdas PA. Depression and pulmonary function in outpatients with asthma. Respir Med 2004; 98: 220-4.

45. Rimington LD, Davies DH, Lowe D, Pearson MG. Relationship between anxiety, depression, and morbidity in adult asthma patients. Thorax 2001; 56: 266-71.
46. Richardson LP, Lozano P, Russo J, McCauley E, Bush T, Katon W. Asthma symptom burden: relationship to asthma severity and anxiety and depression symptoms. Pediatrics 2006; 118: 1042-51.

47. McCauley E, Katon W, Russo J, Richardson L, Lozano P. Impact of anxiety and depression on functional impairment in adolescents with asthma. Gen Hosp Psychiatry 2007; 29: 214-22. 